\title{
KONTRIBUSI SEKTOR PERTANIAN TERHADAP PRODUK DOMESTIK REGIONAL BRUTO KABUPATEN KULON PROGO
}

\author{
Dhea Ayu Resky Amalia ${ }^{1}$, Wahyu Adhi Saputro ${ }^{2}$ \\ ${ }^{1,2}$ Program Studi Agribisnis, Fakultas Sains dan Teknologi,Universitas Duta Bangsa Surakarta \\ E-mail: ayudhea@gmail.com ${ }^{1}$,wahyuadhi@udb.ac.id ${ }^{2}$
}

\begin{abstract}
ABSTRAK
Pertumbuhan ekonomi dapat dicapai dengan adanya peningkatan pendapatan masyarakat yang berujung pada masyarakat yang lebih sejahtera terutama petani. Peran srategis saat ini diemban oleh sektor pertanian yang masuk dalam sektor strategis sebagai penyumbang devisa cukup besar. Salah satu daerah yang memiliki potensi sektor pertanian cukup besar adalah Kabupaten Kulon Progo. Penelitian ini bertujuan untuk mengetahui kontribusi sektor pertanian terhadap produk domestik regional bruto Kabupaten Kulon Progo. Data yang digunakan dalam penelitian ini adalah data sekunder yang bersumber pada Badan Pusat Statistika Kabupaten Kulon Progo. Data yang digunakan adalah data time series PDRB Kabupaten Kulon Progo tahun 2014 hingga tahun 2020. Analisis data yang digunakan dalam penelitian ini menggunakan metode kontribusi dengan membagi sektor pertanian dengan nilai PDRB pada tahun yang sama. Berdasarkan hasil penelitian dapat diketahui bahwa kontribusi sektor pertanian terhadap PDRB Kabupaten Kulon Progo bernilai positif. Kontrbusi sektor pertanian cukup tinggi berada pada tahun 2015 dengan nilai kontribusi sebesar 20,42\% terhadap PDRB Kabupaten Kulon Progo. Kontribusi sektor pertanian terendah terhadap PDRB kabupaten Kulon Progo terdapat pada tahun 2019 dengan nilai kontribusi senilai 15,89\%.
\end{abstract}

Kata Kunci: Sektor, Pertanian, PDRB, Kulon Progo

\section{I.PENDAHULUAN}

Kebijakan pembangunan pada wilayah atau daerah tertentu memiliki tujuan sebagai upaya peningkatan kesejahteraan pada masyarakat secara luas. Hal tersebut dimulai dengan adanya pertumbuhan dan perkembangan ekonomi. Daerah yang mengalami pertumbuhan ekonomi dapat dilihat pada indikator masyarakat yang memiliki kegiatan ekonomi cukup tinggi jika dibandingkan dengan periode sebelumnya. Dengan begitu akan terjadi produk domestik bruto yang naik secara riil. Sektor potensial pada daerah-daerah di Indonesia biasanya bersumber pada sektor pertanian yang memiliki sumbangsih terhadap manjunya ekonomi pada daerah tertentu. Perekonomian yang tumbuh dan berkembang tersebut dapat terlihat dari pendapatan dan serapan tenaga kerja. Manusia hakikatnya akan membutuhkan sektor pertanian dengan adanya hasil pertanian manusia dapat bertahan hidup dan mampu mendukung bahan baku dalam industri. Sektor pertanian dapat terbagi menjadi beberapa sektor seperti perkebunan, perikanan, kehuntana, peternakan dan tanaman bahan pangan (Albertis, 2018).

Pengaruh kekuatan ekonomi pada daerah tertentu yang memadai akan membawa dan menyebar ke banyak sektor baik sektor unggulan maupun non unggulan. Kesempatan kerja pada beberapa sektor unggulan dipengaruhi oleh sisi pendapatan dan dipengaruhi juga oleh sektor-sektor lain. Banyak sekali daerah di Indonesia yang masih mengandalkan sektor pertanian sebagai sektor unggulan yang mampu dijadikan sebagai tonggak pembangunan daerah (Zahari, 2017).

Kegiatan yang dinilai sebagai sebuah proses dalam menambah produksi pertanian dengan menghasilkan adanya perubahan kondisi masyarakat seperti taraf hidup, perilaku, nilai dan norma merupakan pengertian dari pembangunan pertanian. Pertumbuhan ekonomi dapat dicapai dengan adanya peningkatan pendapatan masyarakat yang berujung pada masyarakat yang lebih sejahtera terutama petani. Peran srategis saat ini diemban oleh sektor pertanian yang masuk dalam sektor strategis sebagai penyumbang devisa cukup besar. Indonesia memiliki banyak penduduk yang bermata pencaharian sebagai petani sehingga sumber ekonomi sebagian besar penduduknya berasal dari sektor 
pertanian dan tentunya serapan tenaga kerja terbanyak berasal dari sektor pertanian. Akan tetapi tenaga kerja yang dimaksud atau dalam hal ini adalah petani rata-rata memang tidak memiliki pendidikan yang cukup, keterampilan yang kurang memadai dan pendapatan yang kurang kondisi tersebut menyebabkan petani tidak memiliki bargaining power yang kuat sehingga berpengaruh terhadap nilai jual produk yang sering tertekan akan keadaan (Esther, 2015).

Pembahasan mengenai permasalahan pembangunan yang ada di Indonesia tentunya tidak dapat dilepaskan dengan upaya berbagai macam sektor perekonomian yang menjadi bagian dari pengembangan daerah yang ada di Indonesia. Hal tersebut dikarenakan terdapat adanya tidak merata pertumbuhan ekonomi pada daerah-daerah yang ada di Indonesia. Pembangunan ekonomi yang direncanakan tidak bisa dianggap sebagai rancangan utama dalam menyelesaikan sektor-sektor yang menciptakan nilai-nilai bersumberdaya namun harus didukung oleh banyak sektor yang dianggap sebagai unggulan (Tirani dkk, 2018).

Cerminan keberhasilan pembangunan ekonomi daerah terlihat pada indikator nilai Produk Domestik Regional Bruto (PDRB) dari setiap perkembangan periode waktu. Manfaat dari adanya nilai PDRB yang berkembang dan meningkat tentunya akan berimbas pada perencanaan pembangunan di periode berikutnya. Pembangunan ekonomi yang terjadi tentunya tidak lepas dari dukungan dari daerah tingkat terendah atau regional hingga tingkat pusat yang terlihat pada sembilan sektor perkonomian. Sektor pertanian sendiri merupakan sektor yang memberikan kontribusi cukup besar dalam pembangunan perekonomian (Bembok dkk, 2020). Salah satu daerah yang mengalami perkembangan adalah Kabupaten Kulon Progo. Tentunya daerah tersebut didukung oleh kecamatankecamatan di dalamnya yang memiliki subsektor basis berbeda diikuti dengan jumlah sektor basis yang berbeda pula. Kinerja subsektor pertanian pada masing-masing aderah tersebut dipengaruhi dari potensi manusia, alam dan kebijakan pemerintah (Wicaksono, 2011). Berdasarkan hal tersebut maka penelitian ini bertujuan untuk mengetahui kontribusi sektor pertanian terhadap PDRB Kabupaten Kulon Progo.

\section{II.KAJIAN LITERATUR TERDAHULU}

Salah satu indikator penting dalam menentukan pembangunan ekonomi pada suatu wilayah bahkan negara adalah teori pertumubuhan ekonomi. Teori ini digunakan untuk meliat aktivitas perekonomian wilayah dapat tumbuh sejauh mana dengan hasil tambahan pendapatan masyarakat pada waktu tertentu. Proses ini menggunakan faktor-faktor produksi dalam penghasilan output yang dimiliki oleh masyarakat sehingga aktivitas perekonomian dapat berjalan sebagaimana mestinya dan proses ini menghasilkan balas jasa faktor produksi. Adanya pertumbuhan ekonomi diharapkan akan selaras dengan naiknya pendaptan masyarakat dan faktor kepemilikkan juga akan meningkat. Pertumbuhan terjadi jika balas jasa riil dalam penggunaan faktor produksi pada periode saat ini lebih tinggi jika dibandingkan dengan periode sebelumnya. Kegiatan ekonomi pada dasarnya akan diikuti adanya perkembangan ekonomi scara fisik. Pertambahan yang dimaksd adalah adanya produksi baik segi barang dan jasa serta infrastruktur yang berkembang. Semua hal tersebut biasanya diukur dari perkembangan pendapatan nasional riil yang dicapai suatu negara dalam periode tertentu (Syahroni, 2016).

Pertumbuhan ekonomi dipengaruhi oleh beberapa faktor seperti sumber daya alam, akumulasi modal, pertumbuhan penduduk dan angkatan kerja, kemajuan teknologi. Sumber daya lama merupakan hal utama yang berpengaruh terhadap perekonomian daerah. Hal tersebut tercermin dalam adanya sumber alam dan tanah dimana cakupan tanah merupakan kesuburan tanah, letak, mineral, dan sebagainya sedangkan sumber alam juga hal yang penting karena dapat membangun negara dengan cepat. Akumulasi modal yang tercukupi mampu mendorong pertumbuhan ekonomi dengan adanya investasi sehingga output dan pendapatan dapat dimaksimalkan. Selain itu pengadaan pabrik dengan 
mesin dan peralatan baru sehingga capital sctok kuat membuat negara terebut memiliki cadangan output di periode mendatang. Tentunya investasi harus diimbangin dengan infrastruktur yang mencukupi. Akumulasi modal akan menambah sumber daya baru atau meningkatkan kualitas sumber daya yang sudah ada. Salah satu faktor yang signifikan dan positif dalam memicu pertumbuhan ekonomi adalah pertumbuhan penduduk dan angkatan kerja. Semakin tinggi jumlah penduduk makan akan menyumbang tenaga kerja produktif yang lebih banyak sehingga pertumbuhan penduduk tersebut mendurung ukuran pasar domestik yang kian mebesar. Banyaknya jumlah penduduk angkatan kerja juga mepengaruhi pertumbuhan ekonomi yang ada. Kemajuan teknologi juga dianggap sebagai pemicu pertumbuhan ekonomi dengan penggunaan teknologi maka akan memangkas cara lama dalam melakukan pekerjaan sehingga akan lebih efisiend an efektif (Junaidi dan Zulgani, 2011).

\section{III.METODE PENELITIAN}

Penelitian ini menggunakan metode deskriptif analitik. Lokasi penelitian adalah Kabupaten Kulon Progo. Pemilihan lokasi tersebut dilakukan secara sengaja dikarenakan wilayah ini mengalami pembangunan secara pesat terutama dengan adanya pembangunan bandara internasioanl. Penggunaan data sekunder digunakan dalam penelitian ini. Data sekunder diperoleh dari beberapa sumber seperti buku, jurnal dan sumber lain yang dirasa relevan dengan penelitian ini. Data yang digunakan dalam penelitian ini merupakan data tahunan atau time series yang bersumber dari Badan Pusat Statistik Kabupaten Kulon Progo menggunakan data Produk Domestik Regional Bruto pada tahun 2014 hingga tahun 2020. Analisis data yang digunakan dalam penelitian ini adalah kontribusi sektor petanian terhadap total PDRB Kabupaten Kulon Progo. Tujuan pertama mengenai kontribusi dapat dicari meggunakan rumus berikut (Saputro dan Wiwik, 2020) :

$$
\mathrm{Z}=\mathrm{A} / \mathrm{B} \times 100 \%
$$

Keterangan :

$\mathrm{Z}=$ Kontribusi Sektor Pertanian (\%)

$\mathrm{A}=$ Total Pertanian. Kehutanan dan Perikanan (Juta Rupiah)

B = PDRB Atas Dasar Harga Berlaku Kabupaten Kulon Progo (Juta Rupiah)

\section{IV.HASIL DAN PEMBAHASAN}

Tabel 1. PDRB Kabupaten Kulon Progo Atas Dasar Harga Berlaku

\begin{tabular}{|c|c|c|c|c|c|c|c|c|}
\hline Kategori & Uraian & 2014 & 2015 & 2016 & 2017 & 2018 & 2019 & 2020 \\
\hline A & $\begin{array}{l}\text { Pertanian. } \\
\text { Kehutanan dan } \\
\text { Perikanan }\end{array}$ & 1.422 .659 & 1.566 .769 & 1.656 .160 & 1.725 .388 & 1.817 .768 & 1.906 .259 & 1.959 .623 \\
\hline B & $\begin{array}{l}\text { Pertambangan } \\
\text { dan } \\
\text { Penggalian }\end{array}$ & 101.818 & 109.892 & 115.206 & 131.693 & 169.286 & 177.131 & 167.512 \\
\hline $\mathrm{C}$ & $\begin{array}{l}\text { Industri } \\
\text { Pengolahan }\end{array}$ & 871.865 & 925.813 & 1.023 .907 & 1.124 .647 & 1.240 .604 & 1.321 .327 & 1.305 .125 \\
\hline D & $\begin{array}{l}\text { Pengadaan } \\
\text { Listrik dan } \\
\text { Gas }\end{array}$ & 4.859 & 5.658 & 6.824 & 8.245 & 9.015 & 10.022 & 9.834 \\
\hline $\mathrm{E}$ & $\begin{array}{l}\text { Pengadaan } \\
\text { Air. } \\
\text { Pengelolaan } \\
\text { Sampah. } \\
\text { Limbah dan } \\
\text { Daur Ulang }\end{array}$ & 10.007 & 10.522 & 11.007 & 11.965 & 12.779 & 13.918 & 14.312 \\
\hline $\mathrm{F}$ & Kontruksi & 602.695 & 649.776 & 708.405 & 824.923 & 1.276 .840 & 2.388 .774 & 1.962 .138 \\
\hline
\end{tabular}




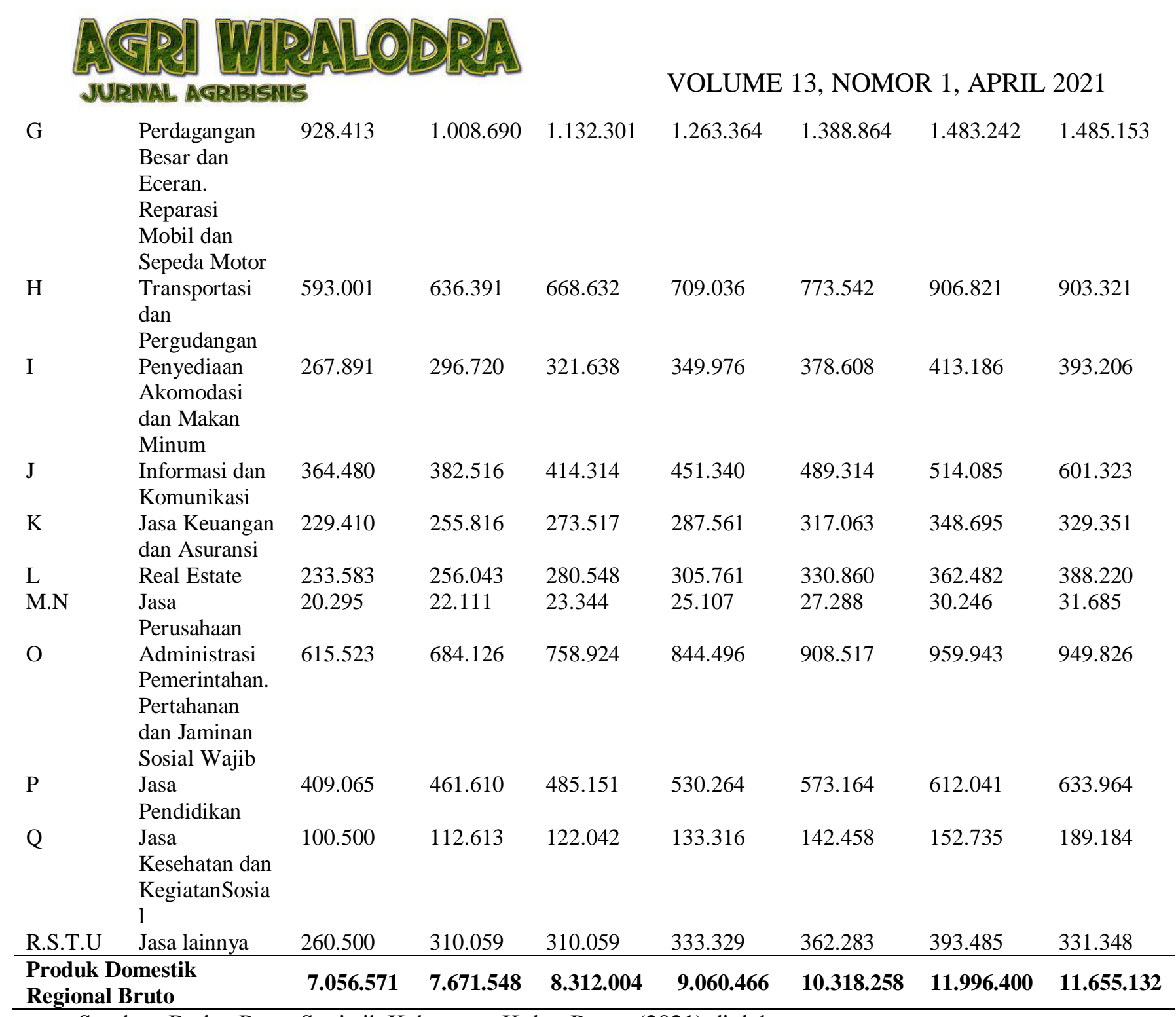

Sumber: Badan Pusat Statistik Kabupaten Kulon Progo (2021) diolah

Isu-isu ekonomi yang bekembang tentunya harus diselesaikan dengan pemberian solusi jangka pendek dan panjang sehingga pembangunan ekonomi daerah tetap berjalan sebagai mana mestinya. Hal tersebut juga harus diselaraskann dengan kebijakan yang ada sehingga kebijakan yang kurang tepat dapat diperbaiki. Pembangunan daerah pada dasarnya merupakan bagian dari pembangunan secara menyeluruh. Pengenalan ekonomi wilayah dan rumusan manajemen pembangunan daerah merupakan dua prinsip dasar yang harus dilakukan dalam melakukan pembangunan ekonomi daerah. Kenaikan pendapatan riil perkapita merupakan imbas dari adanya pembangunan ekonomi aderah dan dalam jangka panjang akan diikuti dengan perbaikan sistem kelembangaan. Terdapat empat unsur pokok dan sifat pokok dalam pembangunan daerah seperti perubahan kontinu, peningkatan pendapatan perkapita, peningkatan pendapatan jangka panjang, perbaikan sistem kelembagaan. PDRB merupakan nilai tambah gross value added yang muncul dari sektor perekonomian pada wilayah tertentu dan dalam waktu tertentu biasanya tahunan maupun semesteran. Tabel 1 merupakan PDRB Kabupaten Kulon Progo pada tahun 2014-2020.

Berdasarkan tabel 1 dapat diketahui bahwa sektor pertanian dari tahun ketahun di Kabupaten Kulon Progo mengalami peningkatan secara signifikan. Pada tahun 2014 hingga tahun 2015 sektor pertanian, kehutanan dan perikanan mengalami peningkatan sebesar 9,20\%. Peningkatan sektor pertanian pada tahun 2015-2016 dan 2016-2017 berkisar pada angka 5,39\% dan 4,01\%. Peningkatan sektor pertanian juga terjadi pada tahun 2017 hingga tahun 2018 sebesar 5,08\%. Peningkatan sektor pertanian pada tahun 2018-2019 dan 2019-2020 berkisar pada angka 4,64\% dan 2,72\%. Peningkatan 
sektor pertanian juga diikuti dengan kenaikan nilai produk domestik bruto pada setiap tahunnya namun terdapat penurunan PDRB yang terjadi pada tahun 2019 menuju tahun 2020. Peningkatan nilai PDRB pada tahun 2014-2015 dan 2015-2016 berkisar pada angka 8,01\% dan 7,70\% sedangkan peningkatan nilai PDRB pada tahun 2016-2017 dan 2017-2018 berada pada angka 12,18\% dan 13,98\%. Jika dilihat pada angka pertumbuhan PDRB nilai tertinggi terdapat pada tahun 2019 hal tersebut tidak terlepas dari upaya pemerintah baik daerah maupun pusat membangun infrastuktur berupa bandara internasional di Kabupaten Kulon Progo sehingga hal tersebut akan menaikkan pembangunan ekonomi dan menaikkan banyak sisi sehingga mendongkrak pendapatan masyarakat di Kabupaten Kulon Progo

Tabel 2. Kontribusi Sektor Pertanian Terhadap PDRB Kabupaten Kulon Progo

\begin{tabular}{cccc}
\hline Tahun & $\begin{array}{c}\text { Pertanian. Kehutanan dan } \\
\text { Perikanan }\end{array}$ & PDRB & Kontribusi (\%) \\
\hline 2014 & 1.422 .659 & 7.056 .571 & 20,16 \\
2015 & 1.566 .769 & 7.671 .548 & 20,42 \\
2016 & 1.656 .160 & 8.312 .004 & 19,92 \\
2017 & 1.725 .388 & 9.060 .466 & 19,04 \\
2018 & 1.817 .768 & 10.318 .258 & 17,61 \\
2019 & 1.906 .259 & 11.996 .400 & 15,89 \\
2020 & 1.959 .623 & 11.655 .132 & 16,81 \\
\hline
\end{tabular}

Sumber: Badan Pusat Statistik Kabupaten Kulon Progo (2021) diolah

Berdasarkan tabel 1 dapat diketahui bahwa terdapat kontribusi sektor pertanian terhadap PDRB Kabupaten Kulon Progo. Pada tahun 2014 kontribusi sektor petanian terhadap PDRB berada pada kisaran nilai 20,16\% dan meningkat pada tahun 2015 menjadi 20,42. Peningkatan tersebut dikarenakan peningkatan sektor peratanian masih lebih besar dibandingkan peningkatan nilai PDRB Kabupaten Kulon Progo pada tahun tersebut. Namun terjadi penurunan nilai kontribusi sektor pertanian pada tahun 2016 hingga 2019 terhadap PDRB Kabupaten Kulon Progo. Sektor pertanian mengalami penurunan seiring dengan konversi lahan pertanian yang cukup tinggi dikarenakan banyak sebab karena hilangnya lahan digantikan lahan bandara yang dimungkinkan melemahkan sektor pertanian namun menguatkan sektor lain. Peningkatan sektor pertanian mengalami peningkatan pada tahun 2019 hingga tahun 2020 sebanyak 0,92\%. Sektor pertanian merupakan sektor potensial yang ada di Kabupaten Kulon Progo. Hal tersebut senada dengan penelitian Thohir (2013) yang menyatakan bahwa sektor pertanian di Kabupaten Kulon Progo merupakan sektor basis dan unggulan dengan dukungan adanya sumber daya lahan yang terhambar di seluruh wilayah Kabupaten Kulon Progo sehingga dapat dijadikan sebagai komponen penunjang dalam meningkatkan produksi pertanian. Sektor pertanian di Kabupaten Kulon Progo memiliki beberapa komoditi yang patut untuk dikembangkan dan dikelola dengan baik sehingga mendukung dalam majunya perekonomian Kulon progo. Pemerintah daerah dalam mempertahankan hal tesebut melakukan banyak upaya salah satunya dengan memberikan penyuluhan pertanian yang intensif. Bantuan sarana produksi pertanian dan pemberian kredit dengan bunga rendah dapat dilakukan agar petani mudah dalam mengelola produk pertaniannya.

\section{Kesimpulan}

Berdasarkan hasil penelitian dapat diketahui bahwa kontribusi sektor pertanian terhadap PDRB Kabupaten Kulon Progo bernilai positif. Kontrbusi sektor pertanian cukup tinggi berada pada tahun 2015 dengan nilai kontribusi sebesar 20,42\% terhadap PDRB Kabupaten Kulon Progo. Kontribusi sektor pertanian terendah terhadap PDRB kabupaten Kulon Progo terdapat pada tahun 2019 dengan nilai kontribusi senilai 15,89\%. Adanya kontribusi sektor pertanian menandakan bahwa sektor tersebut memiliki kontribusi jika dibandingkan dengan sektor lain. Dengan kata lain bahwa sektor pertanian merupakan sektor potensial di Kabupaten Kulon Progo. Sebaiknya pemerintah daerah mengelola lebih baik semua yang ada di sektor pertanian baik sub sektornya termasuk kehutanan dan 
perikanan. Hal tersebut dikarenakan terdapat penurunan kontribusi sektor pertanian pada beberapa tahun sehingga perlu pemfokusan pembangunan sektor pertanian yang masih bisa dapat dimasksimalkan potensinya.

\section{Ucapan Terima Kasih}

Penulis mengucapkan terimakasih yang sebanyak-banyaknya kepada semua pihak yang telah membantu dan mendukung, baik dari pendanaan, waktu dan tenaga. Sehingga penelitiian dengan judul "Kontribusi Sektor Pertanian Terhadap Produk Domestik Regional Bruto Kabupaten Kulon Progo" dapat terlaksana dengan baik.

\section{DAFTAR PUSTAKA}

Albertis. (2018). Kontribusi Sektor Pertanian dan Pengaruhnya Terhadap Perekonomian Daerah Provinsi Jambi. J-MAS (Jurnal Manajemen dan Sains), 4(1), 96-101.

Bembok, N. Kapantow, GHM. Rengkung, LR. (2020). Kontribusi Sektor Pertanian Dalam Perekonomian Di Kabupaten Minahasa. Agri-SosioEkonomi Unsrat,16 (3) : 333 - 342.

BPS. 2014-2020. Kulon Progo Dalam Angka. DIY: BPS Kabupaten Kulon Progo

Esther, Aphrodite. Lexy. (2015). Sektor Pertanian Merupakan Sektor Unggulan Terhadap Pembangunan Ekonomi Provinsi Maluku. Agriekonomika.

Junaidi,J; Zulgani,Z. (2011). Peranan Sumberdaya Ekonomi dalam Pembangunan Ekonomi Daerah. Jurnal Pembangunan Daerah, Edisi 3, 27-33

Saputro, WA. Sariningsih, W. 2020. Kontribusi Pendapatan Usahatani Kakao Terhadap Pendapatan Rumah Tangga Petani di Taman Teknologi Pertanian Nglanggeran Kecamatan Patuk Kabupaten Gunungkidul. Jurnal SEPA. Vol 16 (2).

Syahroni. (2016). Analisis Peranan Sektor Pertanian Dalam Perekonomian Kabupaten Sarolangun. eJurnal Perspektif Ekonomi dan Pembangunan Daerah. 5 (1). 36-44

Thohir, S. (2013). Analisis Sektor Pertanian Dalam Struktur Perekonomian Di Kabupaten Kulon Progo. Economics Development Analysis Journal. 2 (3). 111-117

Tirani. Pranoto, YS. Moelyo, H. (2018). Kontribusi Sektor Pertanian berdasarkan Keunggulan Wilayah di Kabupaten Bangka. Caraka Tani: Journal of Sustainable Agriculture. 33(1), 4249

Wicaksono, I.A. (2011). Analisis Location Quotient Sektor dan Subsektor Pertanian Pada Kecamatan di Kabupaten Purworejo. Mediagro. 7(2), 11-18

Zahari, M., (2017), Pengaruh Pengeluaran Pemerintah Terhadap Pertumbuhan Ekonomi di Provinsi Jambi, Ekonomis, Journal of Economics and Business, 1(1), 180-196 